Cover Page

\title{
Modelling natural ventilation for summer thermal comfort in Mediterranean dwellings
}

\author{
Eftychia Spentzou $^{1 *}$, Malcolm J. Cook ${ }^{1}$, Stephen Emmitt ${ }^{2}$ \\ ${ }^{1}$ Loughborough University, School of Civil and Building Engineering, LE11 3TU, \\ Loughborough, UK \\ ${ }^{2}$ University of Bath, Department of Architecture and Civil Engineering, BA2 7AY, Bath, UK \\ *Corresponding author: Email: e.spentzou@lboro.ac.uk \\ Tel: ++44 (0) 1509222815
}

This research was conducted in Loughborough University 


\title{
Modelling natural ventilation for summer thermal comfort in Mediterranean dwellings
}

\begin{abstract}
There is an urgent need for adequate natural ventilation in apartment dwellers in densely built regions that could improve occupants' summer thermal comfort and reduce the rapidly increasing energy demand for cooling. The aim of the research reported here was to identify natural ventilation strategies that could offer energy efficient refurbishment solutions for domestic buildings whilst maintaining thermal comfort of occupants. An urban multi-storey apartment building in the city of Athens was selected for this study, which is representative of over four-million Greek domestic buildings. Four retrofit strategies were tested with the aim of offering indoor air temperature reductions and increased ventilation rates relative to the existing single-sided ventilation strategy of the building, using computational fluid dynamics (CFD) simulations. The ventilation performance of all strategies varied with wind speed and direction due to the proposed design configurations. During buoyancy driven flows, acceptable ventilation rates for comfort could be achieved with the implementation of a wind-catcher and a dynamic façade. Under wind-driven ventilation, these strategies delivered significant increases in ventilation rate (up to 7 times) and contributed to reductions in indoor air temperatures of up to $2^{\circ} \mathrm{C}$, relative to the existing ventilation strategy. Cooling by water evaporation enhanced the cooling performance of the wind-catcher providing up to $4^{\circ} \mathrm{C}$ temperature reductions. The successful performance of the proposed strategies highlights the potential significance of reducing energy consumption and improving thermal comfort.
\end{abstract}

Key Words: natural ventilation, passive cooling, computational fluid dynamics (CFD), simulation, thermal comfort, Mediterranean dwellings. 


\section{Introduction}

Use of air-conditioning in southern European countries is increasing (Santamouris 2007). By the mid-1990s, more than half of the residential buildings in Greece had installed mechanical cooling (Hassid et al 2000) and the trend has continued. In Greek dwellings, up to $70 \%$ of the occupants now operate air-conditioning systems during summertime and up to $45 \%$ use fans (Drakou et al 2011). Summer heat waves further increase the mechanical cooling peak load demand, threatening to disrupt electrical supply (Kolokotroni et al 2007). The energy required for cooling in hot climates is higher than the energy required for heating (Yun and Steemers 2011). In Greece, the domestic sector, which comprises $79 \%$ of the existing building stock, has the highest energy consumption in Europe (Asimakopoulos et al 2012). Concerns over fuel poverty in more than $20 \%$ of Greek households further highlight the need for low energy (low cost) approaches to ventilation and cooling (Santamouris et al 2007b).

Ventilation is necessary for ensuring acceptable indoor air quality (IAQ) and for providing natural cooling (CIBSE 2005). Increasing ventilation rates can significantly improve the indoor environmental quality of dwellings (Santamouris et al 2007a). However, natural ventilation using typical building openings, e.g. windows or balcony doors, in densely populated urban areas is often insufficient due to the urban design and use of single-side ventilation (Pavlou et al 2007).

Previous studies have explored the performance of natural ventilation solutions in buildings in warm climates (Geros et al 1999; Graça et al 2002; Pavlou et al 2007; Santamouris et al 2010; Givoni 2011; Ford et al 2012; Calautit et al 2012). However, to the authors' knowledge, there is a lack of information available on the performance of natural ventilation systems, such as wind-catchers and dynamic façades, in existing apartment buildings in Mediterranean urban 
climates. The aim of the research reported here was to explore the potential implementation of natural ventilation in existing domestic buildings in the Mediterranean region, using computer simulation, to deliver summertime comfort and improved IAQ. It is hoped that the output of this research could be used to provide guidance for future low energy refurbishments for natural ventilation of a large number of urban domestic buildings in hot climates (i.e. up to four million buildings in Greece alone), which could significantly reduce energy consumption for cooling and provide thermal comfort improvements.

The research was conducted by considering an individual apartment in an urban multi-storey apartment building in the city of Athens. The apartment block is a representative example of the urban architectural typologies in Greece for its design, year and construction type (according to a building classification by Papadopoulos et al (2008)). Thus, modelling this type of apartment has relevance to a significant volume of existing buildings in Athens, and Greece in general (there are up to four million multi-storey apartment buildings in Greece (EL.STAT. 2014)). The ventilation performance of the following natural ventilation strategies was explored: single-sided ventilation; cross ventilation; use of a wind-catcher; use of a dynamic façade of shading systems; and passive downdraught evaporative cooling. These strategies were selected based on their suitability for refurbishment in the case study building, with the aim of enhancing the performance of the existing single-sided ventilation strategy.

\section{Methodology}

\subsection{Overview}

The case study building is an existing five storey domestic building of eight apartments per floor, constructed in the early 1970s. The building is representative of the urban Greek domestic stock, as during this decade, the number of multi-storey domestic buildings 
constructed was more than twice the number of the dwellings (EL.STAT. 2014). The building is located in an urban zone north of the centre of Athens, and experiences a typical Mediterranean climate (Psomas et al 2014). A first-floor two-bedroom apartment was selected $\left(51.4 \mathrm{~m}^{2}\right)$, with living spaces located at the rear (Figure 1). Direct access to daylight and outdoor air is restricted to the two external bedroom openings due to the building design. An airshaft allows the escape of stale air from the core spaces by stack ventilation, through a connecting window to the airshaft. The height of the airshaft is equal to the total height of the building. An extended description of the building design and the apartment studied is included in Spentzou et al (2013).

Natural ventilation strategies were implemented in the case study building by considering the limits imposed by the building form, layout and operation. Combinations of the strategies were expected to achieve the greatest performance. Five ventilation strategies were investigated including the base-case strategy:

I. The base-case ventilation strategy of the apartment was single-sided [SS], using the two existing façade openings and the open internal doors. The internal window connecting to the airshaft was closed.

II. Cross ventilation [CV] was modelled using a similar model to the [SS] case but with the window connecting to the airshaft kept open. The top of the airshaft was protected from precipitation by a suspended lightweight roof allowing air to enter the shaft on two sides.

III. A four-sided wind-catcher [WC] with cross-partitions was placed at the top of the existing airshaft, replacing the suspended roof. The intention of this design was to harness wind from all directions.

IV. The fourth strategy was the wind-catcher combined with a dynamic façade [DF \& WC]. Dynamic façades respond to environmental parameters (i.e. temperature, humidity, solar gains) using automatically controlled shading devices (Hammad and Abu-Hijleh 2010). 
The aim of the dynamic façade strategy was to assist the natural ventilation of the spaces and deliver solar gain reductions with appropriate louvre design. The dynamic façade (extending from floor to ceiling), formed a semi-outdoor environment up to the edge of the balcony, and comprises horizontal louvres that operate in three sections (upper, middle and lower). For the purpose of the study reported here, the dynamic façade was modelled with fully open louvres, represented as three horizontal openings with a discharge coefficient of 0.61. The contribution of shading was not taken into consideration.

V. A traditional technique for passive cooling by water evaporation was incorporated into both the [WC] and [DF \& WC] strategies. These are denoted by [PDEC-WC] and [PDECDF] respectively. The passive downdraught evaporative cooling (PDEC) tower, operates by spraying fine water mist in the core of the wind-catcher shaft and below the cross partitions. The climate of Athens has been acknowledged as suitable for evaporative cooling solutions when operated with control to avoid hours of high humidity (Salmeron et al 2012). Evaporative cooling was modelled as a heat sink with moisture source.

CFD simulations were performed with the general-purpose code PHOENICS (CHAM Ltd. 2013) using the finite-volume method and a structured grid. This code was selected due to its ease of use and because it has been shown to accurately model buoyancy and wind-driven ventilation flows (Papakonstantinou et al 2000; Allocca et al 2003). The domain de-coupling approach was used in this study to perform internal-external airflow simulations. This approach is less time consuming than the coupled approach (Graça et al 2002) in which internal and external airflows are modelled simultaneously, and it offers the potential for optimum mesh refinement and flexibility with design (Norton et al 2007; Jiru and Bitsuamlak 2010). This reduces the computational power required to simultaneously model both internal and external thermal environments. Using the de-coupling approach, the building and its surroundings (nine urban blocks with 103 buildings in total) were first simulated to obtain pressure values at the 
location of the openings, which were subsequently used as boundary conditions at openings for the internal flow study.

For the performance evaluation of the strategies under steady-state conditions, typical climate conditions were identified for the site studied based on frequency and intensity of the dry-bulb temperatures (DBT), wind speeds and wind directions. These were predicted using a representative climate file for the cooling season (Spentzou et al 2013). Simulations were performed for the mean DBT at the site $\left(26^{\circ} \mathrm{C}\right)$. Three different wind conditions were modelled: no wind, a mean wind speed of $3.6 \mathrm{~m} / \mathrm{s}$ (up to $40 \%$ of the wind speeds were between 2.5 and $4.5 \mathrm{~m} / \mathrm{s}$ ); and $7 \mathrm{~m} / \mathrm{s}$ which was the $85^{\text {th }}$ percentile (wind speeds exceeded this for $15 \%$ of the period). The three dominant wind directions were also modelled: north; east; and northwest (which are experienced for $33 \%, 7 \%$ and $12 \%$ of the period respectively), see Figure 2 . The schematic diagram in Figure 3 illustrates the simulation process repeated for each natural ventilation strategy.

Acceptable environmental conditions for indoor air temperature, velocity and air change rates were taken from the literature to assess the performance of each strategy. Guides commonly recommend benchmarks for summer peak temperatures in spaces: CIBSE (2006) recommends peak temperatures of $28^{\circ} \mathrm{C}$ in living spaces and $26^{\circ} \mathrm{C}$ in bedrooms in free-running buildings; British Standards (BS EN15251 CEN 2007) recommend a minimum operative temperature of $22^{\circ} \mathrm{C}$ for existing buildings. However, taking into account occupants' adaptability to their environment, thresholds that are more flexible could be identified; indoor temperatures exceeding $25^{\circ} \mathrm{C}$ could be balanced with increased ventilation rates (BS EN15251 CEN 2007). Despite the low recommended acceptable values of air change rates $\left(0.4\right.$ to $1 \mathrm{ach}^{-1}$ in CIBSE 2006), high values between 5 and $10 \mathrm{ach}^{-1}$ could achieve adequate cooling by ventilation (CIBSE 2005). Previous work has predicted high values of air change rates of up to $5 \mathrm{ach}^{-1}$ 
during wintertime (Santamouris et al 2007a), up to $20 \mathrm{ach}^{-1}$ in cross ventilated Greek apartments (Niachou et al 2005) and even up to $80 \mathrm{ach}^{-1}$ in some naturally ventilated Greek buildings (Geros et al 1999). In addition, higher air speeds can extend the comfort limits and deliver direct cooling (Cândido et al 2011; Givoni 2011). Although $0.2 \mathrm{~m} / \mathrm{s}$ is recommended as the upper acceptable limit of draft perception by ASHRAE Standard 55 (Cândido et al 2008), air velocities of $1 \mathrm{~m} / \mathrm{s}$ could offset the high indoor air temperatures (CIBSE 2005) and between $0.2-1.5 \mathrm{~m} / \mathrm{s}$ are acceptable for thermal comfort (Cândido et al 2008). Lastly, the cooling potential of PDEC strategies evaluated by others have been considered significant achieving up to $16^{\circ} \mathrm{C}$ lower internal air temperature than the external (Ford et al 2012; Givoni 1994).

\subsection{External flow field modelling: settings and boundary conditions}

External flow field simulations were performed for three building models, these were:

- The base-case ventilation strategy that used the existing design of the airshaft, and provided results for the study of the internal flow field of the [SS] and [CV] strategies;

- The inclusion of a wind-catcher, which provided boundary conditions for each of the four wind-catcher openings and the two façade openings for the internal flow study in the [WC] and [PDEC-WC] strategies (Figure 1);

- The addition of the dynamic façade, which provided input values for the four windcatcher openings and three zones of louvres of the strategies [DF \& WC] and [PDECDF].

The case study building was modelled in the centre of nine surrounding urban blocks, which were surveyed on site, to evaluate the flow field around the building within its surroundings and subject to different wind directions (Spentzou et al 2014). The edges of the computational domain in the horizontal directions were located 300m (16 times the building height) from the 
outline of the surrounding buildings, and the vertical size of the domain (136.8m) was more than seven times the height of the building. These resulted in a blockage ratio of less than $1 \%$ and less than the recommended maximum of 3\% (Martins and Carrilho da Graça 2016). A study by Martins and Carrilho da Graça (2016) using wind tunnel modelling and PHOENICS validated this modelling approach and demonstrated its performance.

Average pressure values were calculated at each opening using an additional coding. The flow was isothermal and turbulence was modelled using the modified k-epsilon model of Chen and Kim (1987) that reduces the dissipative nature of the standard k-epsilon by Launder and Spalding (1974). The effects of wind were modelled using a simulation option in the software that creates inflow boundaries at the domain edges with a logarithmic profile on the upwind faces, fixed pressure boundaries on the downward faces and the sky, and by using an effective roughness height of $0.75 \mathrm{~m}$ (Spentzou et al 2014).

Grid control objects, with no effect on the calculations, provided greater control of the threedimensional structured Cartesian mesh. This enabled a fine mesh to be created over the buildings and rapid expansion of the grid further away from the building zone (Figure 4). To achieve a solution independent of the mesh resolution, six different meshes were tested. The CFD model of the wind-catcher strategy [WC] was selected for the mesh investigation due to the complex geometry of the wind-catcher requiring fine mesh elements. Table 1 shows the number of cells in the $\mathrm{x}$ and $\mathrm{y}$ directions for the wind catcher zone, the number of cells in each domain axis and the total number of cells for all six meshes evaluated. The first five meshes converged to an acceptable level, however, convergence was more difficult to achieve for the sixth mesh (Table 1). Mesh 5 was chosen as an acceptable trade-off between accuracy and computational power, and because of the mesh refinement in the region of the wind-catcher. 
All external flow simulations using Mesh 5 reached convergence after approximately 8,000 iterations and within 50 to 130 hours. Convergence could only be achieved by using false timesteps (under-relaxation) of $0.1 \mathrm{~s}$ for each of the three momentum equations. The solution was considered converged when: the values of the pressure and the three velocity components at a defined monitoring point in the domain remained unchanged; and the logarithms of the sums of the absolute residual of each variable (errors) in the finite-volume equation were reduced to a magnitude below 1E-03. The monitoring point used was located at $7.7 \mathrm{~m}$ above the level of the ground and behind the leeward side of the buildings.

\subsection{Study of the internal flow field: Description of the boundary conditions}

For the ventilation performance investigation of the proposed strategies in the case study apartment, four CFD models of internal flow ([SS], [CV], [WC], [DF \& WC]) were created for each strategy (Figure 5). The wind-driven ventilation of the PDEC strategies was evaluated using the CFD models of the [WC] and [DF \& WC] strategies (with the addition of the water evaporation technique in each). For the internal flow study, the case study apartment was modelled without the adjacent building spaces to reduce computational time: the computational domain boundaries were reduced to the outline of the apartment spaces and the adjacent airshaft. Heat gains due to occupants, lighting, and equipment were modelled as volumetric heat sources (Table 2). These remained unchanged for all CFD simulations to provide comparable results. Surfaces were modelled as impermeable, no-slip adiabatic surfaces.

The energy equation was solved for temperature, and buoyancy was modelled using the Boussinesq approximation, whereby density is assumed to be constant except in the source term of the v-momentum equation. For the study of buoyancy-driven flows, the velocity components normal to each external opening were deduced at run-time from the mass flow rate 
divided by the in-cell density and the cell area (Ludwig and Mortimore 2011). Air pressure at the openings was equal to the ambient $(\mathrm{p}=0)$ and loss coefficient equal to 2.69 (Cook et al 2011). For wind-driven flows, Neumann boundary conditions were used whereby the velocity components were equal to those values of the upstream cells.

A mesh sensitivity study was performed for the models of the internal flow: seven different meshes were investigated for the [WC] strategy. These varied by $15 \%$ in terms of the total number of cells in each direction and they were evenly distributed in the $\mathrm{x}$ and $\mathrm{y}$ directions. All seven meshes converged to an acceptable level and provided similar results (Figure 6), although convergence was more difficult to achieve for mesh 6 and mesh 7. Mesh 2 provided acceptable accuracy in the least computational time.

As described in Section 2.1, for the purpose of the study reported here, the dynamic façade was modelled with fully open louvres, but without including the louvres in the CFD model and by representing them with three horizontal openings. This was applied to the [DF \& WC] strategy. To justify this, supplementary CFD simulations were performed in order to evaluate the ventilation performance of the different operations of the louvres, i.e. all open, upper open only, upper and lower open (Figure 7$)$. Due to the small size of the louvres $(4 \times 21 \mathrm{~cm})$, fine mesh elements were created in the region of the louvres, which resulted in the coarser cells in the domain being greater than 40,000 times larger than the finest cell sizes at the louvres.

Convergence was difficult to achieve due to the fine mesh elements requiring up to four times more computational time, relative to the simulations performed excluding the louvres from the design. Indoor air velocities were predicted comparable for the upper and for the upper and lower open louvres. Lower air velocities were predicted for the fully open louvres; however, these were comparable to the predicted values of the models without the louvres. 
PDEC was modelled as a heat sink with moisture content in the airshaft over a finite volume with dimensions $1.1 \times 2.1 \times 9 \mathrm{~m}$ and located above the ceiling level of the case study apartment. This represents a mist of water sprayed and uniformly evaporated. The air entering from the wind catcher's openings passes through the heat sink (the droplets were in the form of saturated air), which reduces its temperature and increases its moisture content. In order to calculate the heat sink used to represent the cooling rate due to water evaporation it was important to consider the seasonal water temperature fluctuations of the site as they vary the water density. The average water temperature during the cooling season (May-September) of the water supply network in Athens (Argiriou et al 2010) was $22.78^{\circ} \mathrm{C}$. The system was evaluated for water consumption of $6 \mathrm{~L} / \mathrm{h}(3.76 \mathrm{~kW})$, according to relevant studies that have predicted adequate cooling performance of PDEC in dwellings for up to $8 \mathrm{~L} / \mathrm{h}$ water consumption (Ford et al 2012).

The airshaft was connected to and shared by eight apartments in total. The case study apartment is located on the first floor, three apartments are located above the case study apartment and four are connected to the airshaft from the opposite side. The performance of the natural ventilation strategies were evaluated for the situation when the other apartments' openings connected to the airshaft were closed. Supplementary CFD simulations were used to investigate the influence of the surrounding apartments on the ventilation performance of the new strategies.

\section{Results}

\subsection{External flow simulations}

The external flow field simulations provided driving pressures (at inlet and outlet) for six wind scenarios and for each of the three building models evaluated (Figure 8). These show the 
ventilation potential of each strategy and climate scenario. For the specific site and building design, north wind directions were predicted to be the most favourable for wind-driven natural ventilation, as indicated by the driving pressures of $30.1 \mathrm{~Pa}$ relative to $11.5 \mathrm{~Pa}$ for northwest wind directions (Figure 8). Accordingly, both the [WC] and [DF \& WC] ventilation strategies generated greater ventilation potential at higher wind speeds (i.e. $7 \mathrm{~m} / \mathrm{s}$ ). Figure 9 illustrates the flow distribution around the nine urban blocks for a north wind direction and wind speed of $7 \mathrm{~m} / \mathrm{s}$.

Exploratory external flow simulations of the case study building with and without (detached) the surrounding buildings were performed. It was predicted that the pressure values on the openings of the detached case could potentially generate a driving pressure of up to $60 \%$ greater than that of the building with its surroundings. This would consequently result in higher and inaccurate values of internal airflow and potentially up to $30 \%$ higher ventilation rates (predicted in a simulation study of the apartment under investigation carried out by the author, not presented here). This was in accordance with work by others in Athenian buildings that found via both measurements and simulations, up to $80 \%$ higher ventilation rates in undisturbed sites relative to urban canyons (Georgakis and Santamouris, 2006). Measurements by Geros et al (2005) in two urban canyons, in close proximity to the site under investigation, predicted an average difference between the wind speed inside and outside of the canyons of approximately $2.5 \mathrm{~m} / \mathrm{s}$. This value is comparable to the values predicted for the site under investigation, which exhibited wind speed differences varying between $1.6-2.1 \mathrm{~m} / \mathrm{s}$ with regard to the different wind directions.

\subsection{Internal flow simulations}


The values of the pressures predicted for the external flow simulations reported in Section 3.1 were used directly at the building openings for the evaluation of the internal flow. All simulations converged according to the criteria previously described in Section 2 . The following were predicted for each natural ventilation strategy investigated.

Single-sided ventilation [SS]: The ventilation performance of the [SS] strategy was considered insufficient to deliver thermal comfort during buoyancy-driven forces with regard to the predicted low (zero in some cases) ventilation rates (Figure 10). Indoor air temperatures of up to $2^{\circ} \mathrm{C}$ above the ambient were predicted for both buoyancy and wind-driven simulations, and under all wind scenarios examined (Figure 11). Niachou et al (2005) explored the natural ventilation performance of a single-sided Athenian apartment, also located on the first floor, and with similar surface area $\left(50 \mathrm{~m}^{2}\right)$ to the case-study apartment under investigation. This study predicted air changes within the range predicted for the case-study apartment $\left(0-6 \mathrm{ach}^{-1}\right.$ depending on the wind direction) (Figure 10) during single-sided ventilation, providing confidence in the results of the simulations reported here.

Cross ventilation $[\mathrm{CV}]$ : The $[\mathrm{CV}]$ strategy under buoyancy-driven forces improved the fresh air distribution within the rear space (kitchen) which is connected via a window to the airshaft and reduced the indoor air temperature by up to $1{ }^{\circ} \mathrm{C}$ compared with the [SS] strategy. Under winddriven forces, the $[\mathrm{CV}]$ contributed to temperature reductions of up to $1.5^{\circ} \mathrm{C}$ and up to 14 times greater ventilation rates relative to the $[\mathrm{SS}]$ strategy. The predicted indoor temperatures in the bedrooms complied with CIBSE (2006). The ventilation performance of the [CV] favoured northwest wind directions due to the building design, which had a low number of occurrences (12\%), thus different ventilation strategies would be required to achieve satisfactory comfort throughout the entire cooling period. Both $[\mathrm{SS}]$ and $[\mathrm{CV}]$ strategies resulted in air change rates comparable to those predicted by others in existing apartments in Athens. Geros et al (2005) 
predicted approximately $10 \mathrm{ach}^{-1}$ for a cross ventilated building in Athens for canyon wind speeds below $1 \mathrm{~m} / \mathrm{s}$. Although this work was conducted for a different building and microclimate, the ventilation rates predicted are of a similar order (i.e. the ratio of air change rates generated to the canyon wind speeds applied was comparable to that determined here), thus providing some confidence in the simulation results reported here.

Wind-catcher [WC]: The inclusion of a wind-catcher [WC] increased the air change rates by $8 \%$ during buoyancy and by up to $76 \%$ during wind-driven flow, relative to the [CV] strategy under steady-state conditions. Wind-driven flows contributed to significant temperature reductions relative to buoyancy-driven flows, and showed an improvement in the flow distribution (Figure 12). These also delivered 56\% on average higher ventilation rates for the different wind directions (up to 85\%) than the buoyancy driven flow. This performance was consistent with published work, which predicted higher ventilation rates during wind driven flows by $76 \%$ (Hughes and Cheuk-Ming 2011). The ventilation rates vary significantly with regard to wind direction (Figure 10); this was also predicted by others who evaluated the performance of wind catchers (Montazeri et al 2010; Calautit et al 2012). This is due to the form/location of the building, the surroundings that influence the flow field around the building, and the form of the proposed strategies. In particular, under north and east wind incidents, the wind-catcher contributed to increased ventilation rates by two to three times relative to the previous $[\mathrm{CV}]$ strategy and reduced the indoor air temperatures by up to $0.5^{\circ} \mathrm{C}$ (Figure 11). This is significant as north and east wind directions account for $40 \%$ of the wind incidents and if considering northeast winds too (Figure 2), comfort could be achieved using the [WC] strategy for up to $70 \%$ of the cooling period.

Combined wind-catcher and dynamic façade [DF \& WC]: The introduction of the dynamic façade enhanced the natural ventilation, delivering higher volume flow rates by up to $40 \%$ at 
the inlets relative to [WC] strategy, due to the opposing wind directions. However, this improved performance was dependent on the wind scenario (direction and speed), and in some cases reduced the performance relative to the $[\mathrm{WC}]$ strategy due to opposing wind directions. For example, air velocities at the internal doors between the bedrooms and the living room, of up to $1.7 \mathrm{~m} / \mathrm{s}$ were predicted, being substantially higher than the other natural ventilation strategies and the minimum recommended values for comfort (CIBSE 2006); the high air movement could provide direct comfort cooling with this strategy. The combined [DF \& WC] strategy, under a buoyancy-driven regime, provided higher indoor air velocities than the [SS] strategy; this demonstrates that even on low wind speed days (wind speeds below $1 \mathrm{~m} / \mathrm{s}$ occurred $23 \%$ of the cooling period, see Figure 2) the new strategies could deliver higher ventilation rates than the base-case ventilation strategy. Shading provided by the dynamic façade was not taken into account, and thus, this strategy [DF \& WC] could provide even higher temperature reductions if the solar gains were eliminated, as predicted by others (Givoni 2011).

Passive downdraught evaporative cooling [PDEC]: The introduction of passive cooling by water evaporation in both the [WC] and [DF \& WC], reduced the indoor air temperatures by up to $5^{\circ} \mathrm{C}$ relative to the initial [SS] strategy, providing lower indoor air temperatures $\left(23^{\circ} \mathrm{C}\right)$ but above the minimum acceptable for comfort (BS EN15251 CEN 2007). Further temperature reductions could be achieved with continuous and controlled operation of the strategy, as was shown by Ford et al (2012) and Givoni (2011), while the rate of water consumption would be governed by the wind speed, wind direction and the ambient temperature. Ford et al. (2012) predicted with real scale measurements that for up to two hours of intermediate performance (i.e. $50 \%$ of the time), a PDEC tower would deliver $1.5^{\circ} \mathrm{C}$ lower indoor temperatures; this is in line with the performance of the [PDEC-WC] strategy that delivered indoor temperature reductions ranging from $0.9^{\circ} \mathrm{C}$ to $4.1^{\circ} \mathrm{C}$ during steady state conditions. 


\section{Discussion and validation assessment}

Results from the CFD simulations demonstrated the potential for wind-driven ventilation to improve upon the buoyancy-driven ventilation strategy (Figure 12). This resulted in reductions in indoor temperatures of up to $0.5^{\circ} \mathrm{C}$ and $1{ }^{\circ} \mathrm{C}$ relative to the buoyancy-driven flows, for $3.6 \mathrm{~m} / \mathrm{s}$ and $7 \mathrm{~m} / \mathrm{s}$ wind speeds respectively (Figure 11). However, simulations showed that for the [DF \& WC] strategy, thermal comfort could be provided during hours of low wind speed (buoyancy-driven). Further to this, the PDEC performed best at low ventilation rates, providing significant temperature reductions, which was in agreement with work by Givoni (1994) reporting up to $16^{\circ} \mathrm{C}$ temperature reductions for an exit velocity (from the airshaft) of $0.75 \mathrm{~m} / \mathrm{s}$. This is significant as thermal comfort could be achieved during periods of low wind speed, which account for up to $23 \%$ of the cooling period.

Air velocities were calculated at the location of the internal doors of the two bedrooms and at a horizontal plane across all spaces at $1.5 \mathrm{~m}$ above the apartment's floor (Figure 13). Air speed was predicted to be non-uniform across the occupied spaces due to the floor layout and the inlets/outlets position. However, the high air speeds measured at the location of the internal doors (up to $1.7 \mathrm{~m} / \mathrm{s}$, presented in Spentzou (2015)) could offset the increased temperature (Cândido et al 2011) and provide thermal comfort, as values up to $1.5 \mathrm{~m} / \mathrm{s}$ could extend the comfort limits in the spaces by up to $4^{\circ} \mathrm{C}$ (BS EN15251 CEN 2007). The predicted average indoor air velocities (Figure 13) would be considered comfortable by the occupants as they were predicted within the acceptable range defined in a study for hot climates by Gong et al (2006). Within this study, the preferred indoor air velocity range was $0.3-0.9 \mathrm{~m} / \mathrm{s}$ for ambient temperatures of $26^{\circ} \mathrm{C}$ (this same ambient temperature value was used in the research reported 
here); which demonstrates the satisfactory performance of the ventilation strategies evaluated within the case-study building.

Wind speed and direction significantly influenced the performance of all strategies, particularly the wind-catcher as also reported by others (Montazeri et al 2010; Calautit et al 2012). Increased wind speeds (e.g. from $3.6 \mathrm{~m} / \mathrm{s}$ to $7 \mathrm{~m} / \mathrm{s}$ ) resulted in 4.6 times greater ventilation rates in the [SS] strategy. Other published work has demonstrated significant variations of the internal flow due to wind direction fluctuations (Spentzou et al 2016). The same increase in wind speed resulted in 2.1 times greater ventilations rates in the [DF \& WC] strategy. The predicted air change rates varied in response to wind directions by a factor of up to $14,4,4$, and 3 for the [SS], [CV], [WC], and [DF \& WC] strategies respectively (Figure 10). This performance is dependent on the geometry of the urban canyon, which modifies the wind direction and speed, and therefore these results should not be directly compared to other similar cases. The ventilation and cooling performance of the majority of the strategies increased for northerly winds, as higher ventilation rates were delivered. This was due to the design of the strategies, the building and the surroundings geometries, and the floor layout of the apartment studied. As north is the dominant wind direction at the site with the highest number of incidents during the cooling period (33\% of wind incidents as shown in Figure 2), the new ventilation strategies could provide comfort for a significant time during the cooling period. For all strategies and wind speeds evaluated, the predicted indoor temperatures varied by up to approximately $1 \%$ in response to the wind directions.

All strategies delivered air change rates above the minimum acceptable values for comfort according to the standards used in this work (see Section 2 Methodology), except for the basecase strategy [SS]. Air change rates significantly exceeded the minimum for IAQ under certain wind scenarios, particularly for the [DF \& WC] strategy $\left(44 \mathrm{ach}^{-1}\right.$ on average), as shown in 
Figure 10. However, these values represent steady-state conditions that would vary throughout the ventilation period. In addition, these values agree with air changes measured in existing free running buildings in Greece, which showed particularly high values of $20 \mathrm{ach}^{-1}$ on average and up to $80 \mathrm{ach}^{-1}$ (Geros et al 1999). If these values are delivered during the night, they could provide cooling during the day, and delay the peak temperatures (Geros et al 1999; Givoni 2011). Therefore, the potential contribution of the ventilation strategies in delivering natural cooling is substantial.

The ventilation performance of the strategies in the apartment studied were also evaluated with all the adjacent apartments (seven plus the case study) using the airshaft for natural ventilation. Air change rates (Figure 10) were predicted to be $66 \%$ lower on average when the airshaft was being used by all apartments, relative to it being used only by the case study apartment. Air change rates predicted for buoyancy-driven flow and for wind-driven flow of $3.6 \mathrm{~m} / \mathrm{s}$ were comparable for all strategies. However, even during low wind speeds, air change rates were predicted above the minimum values required for IAQ (on average $12 \mathrm{ach}^{-1}$ for $3.6 \mathrm{~m} / \mathrm{s}$ and the [WC]). Despite the reduced ventilation performance of the strategies when the airshaft is being used by all apartments, high values of air change rates (up to $39 \mathrm{ach}^{-1}$ ) were predicted for higher wind speeds $(7 \mathrm{~m} / \mathrm{s})$, and the [WC] strategy provided up to three times greater ventilation rates than the $[\mathrm{CV}]$ strategy. As previously described, the cooling performance of the PDEC strategies improved at low ventilation rates and thus the reductions in ventilation rates when the airshaft was shared by all apartments benefited the performance of the PDEC strategies, which provided further temperature reductions of up to $3.6^{\circ} \mathrm{C}$. The [PDEC-DF] strategy achieved the lowest than indoor air temperatures of all the strategies tested, as low as $19.8^{\circ} \mathrm{C}$ for ambient temperatures of $26^{\circ} \mathrm{C}$ with east wind of $3.6 \mathrm{~m} / \mathrm{s}$. Thus, it is likely that comfort could be achieved even when the airshaft was shared by all apartments. 
A validation assessment of the external and internal flow models was performed in order to determine the degree to which the models agree with real world observations. For both cases, solution convergence and grid sensitivity were examined (see Sections 2.2 and 2.3). The relationships established between wind speed and driving pressure, and between driving pressure and ventilation rates, were evaluated using regression analysis. This was achieved by performing an additional number of simulations for each ventilation strategy and model (external and internal), which subsequently generated multiple points in order to confirm these relationships. Specifically, simulations for an additional number of wind scenarios (speeds and directions) were performed for all the external flow models, which provided further driving pressures that confirmed the relationship between pressure difference and wind speeds. For the [WC] ventilation strategy, the relationship between driving pressures and wind speeds is presented in Figure 14. The relationship established in all cases shows $\Delta \mathrm{P} \propto \mathrm{U}^{2}$, which agrees with Bernoulli's equation and therefore provides confidence in the CFD model of the external flow and the results predicted. With regard to the internal flow model for the different ventilation strategies, the relationships defined between driving pressure and ventilation rates agree with Equation 2.11 in CIBSE Guide B (2005), showing $\mathrm{Q}_{\mathrm{w}} \propto \Delta \mathrm{Cp}^{0.5}$ where $\mathrm{Q}_{\mathrm{w}}$ is the airflow rate due to wind alone $\left(\mathrm{m}^{3} / \mathrm{s}\right)$ and $\Delta C_{\mathrm{p}}$ is the difference in pressure coefficient between inlet and outlet. This relationship was established for all ventilation strategies, predicting comparable regression equations with high $\mathrm{R}^{2}$ values $(>0.99)$, suggesting that the regression model appropriately explains the variation between the two variables. This provides confidence in the CFD results of the internal flow field, presented in Section 3.2. An extended description of this validation assessment is included in Spentzou (2015).

A further study evaluated the use of steady-state modelling when assessing natural ventilation in buildings, reported in Spentzou et al (2015). A number of transient CFD simulations were performed for the case study apartment and the cross ventilation strategy [CV]. The influence 
of boundary and environmental conditions (i.e. ambient temperature, wind speed, indoor wall surface temperature, and heat gains) on the indoor air conditions were investigated in order to study the response time of the buoyancy and/or wind-driven airflow regimes. The timedependent simulation results with time steps between 5 and 30 minutes (24-hour period) were plotted against the steady-state results. A strong correlation between the steady-state and timedependent results was observed with less than $0.1 \%$ and $1 \%$ errors with regard to variations of the ambient temperature and the wind speed respectively; this justifies the use of the steadystate modelling.

\section{Conclusions}

The results from this study show that it is possible to implement natural ventilation strategies in domestic buildings and provide occupants' thermal comfort without the use of mechanical cooling. The potential of the strategies to reduce energy consumption during at the case study building has been demonstrated through CFD simulations, which is important given that this building type is very common throughout the Mediterranean.

Principal findings from this study include:

- Evaluating the ventilation performance of buildings within their urban environment predicts driving pressures with greater accuracy. In this study, up to $60 \%$ higher driving pressures were predicted when the building was modelled without its surrounding buildings.

- The ventilation performance of the wind catcher was significant relative to simple single-sided or cross ventilation strategies; indoor temperatures were predicted to be up to $2^{\circ} \mathrm{C}$ lower. 
- Cross ventilation improved the indoor air distribution and increased the very low ventilation rates that were predicted during the single-sided ventilation (close to zero). These were increased by up to $76 \%$ with the implementation of the wind-catcher. The performance of the combined dynamic façade and wind-catcher was able to increase the ventilation rates by a further $40 \%$.

- Passive downdraught evaporative cooling performs well at low ventilation rates and could provide cooling during low wind speed periods, delivering up to $5^{\circ} \mathrm{C}$ lower indoor air temperatures.

- Thermal comfort can be achieved even during periods of low wind speeds using buoyancy-driven natural ventilation strategies; potentially for up to $23 \%$ of the cooling period using the [DF \& WC] strategy.

- The proposed strategies provided air change rates that were higher than the minimum required (above $10 \mathrm{ach}^{-1}$ ), which could offset high temperatures and contribute to occupant's thermal comfort.

- The combined [DF \& WC] strategy was the most efficient solution for the Mediterranean sub-climate and building type studied. This would be the recommended strategy, supplemented with evaporative cooling for further temperature reductions.

Natural ventilation has been shown to be a viable refurbishment option that could promote sustainable refurbishment of the existing building stock. The output of this research will be used to produce a low-energy refurbishment design guide, with the aim of assisting designers in dealing with the implementation of natural ventilation strategies in domestic buildings.

\section{Acknowledgements}

The authors would like to thank Dr David Glynn (Cham Ltd) for his assistance during the development of the CFD models. 


\section{References}

Allocca C, Chen Q, Glicksman LR. "Design analysis of single-sided natural ventilation", Energy Build 2003 35(8) pp785-795 doi: 10.1016/S0378-7788(02)00239-6

Argiriou A, Gaglia A, Daskalaki E, Zaharias P, Katsanos D, Kontogiannidis S, Ladopoulos G, Ladopoulos I. T.O.T.E.E. 20701-3/2010 Climate data of Greek Cities [In Greek], Technical Directive by the Technical Chamber of Greece 2010 Athens.

Asimakopoulos DA, Santamouris M, Farrou I, Laskari M, Saliari M, Zanis G, Giannakidis G, Tigas K, Kapsomenakis J, Douvis C, Zerefos SC, Antonakaki T, Giannakopoulos C. "Modelling the energy demand projection of the building sector in Greece in the 21st century", Energy Build 201249 pp488-498 doi: 10.1016/j.enbuild.2012.02.043

BS EN15251 CEN. "Indoor environmental input parameters for design and assessment of energy performance of buildings addressing indoor air quality, thermal environment, lighting and acoustics", Thermal Environment, Lighting and Acoustics AFNOR British Standards Institute (BSI), London UK, 2007 Vol. 3

Calautit JK, Hughes BR, Ghani SA. "A numerical investigation into the feasibility of integrating green building technologies into row houses in the Middle East", Archit Sci Rev 2012 pp1-18. doi: 10.1080/00038628.2012.686433

Cândido C, de Dear R, Lamberts R, Bittencourt L. "Natural ventilation and thermal comfort: air movement acceptability inside naturally ventilated buildings in Brazilian hot humid zone", In: Air Conditioning and the Low Carbon Cooling Challenge, Cumberland Lodge, Windsor, UK, 2008 27-29. London: Network for Comfort and Energy Use in Buildings

Cândido C, Lamberts R, de Dear R, Bittencourt L, de Vecchi R. "Towards a Brazilian standard for naturally ventilated buildings: guidelines for thermal and air movement acceptability", Build Res Inf 2011 39(2) pp145-153 doi: 10.1080/09613218.2011.557858

CHAM Ltd. PHOENICS, UK-Headquarters Concentration Heat and Momentum Limited Wimbledon Village, London, software version 2012, www.cham.co.uk/phoenics, 2013

Chen YS, Kim SW. Computation of turbulent flows using an extended k-epsilon turbulence closure model, NASA-CR-179204, United States, 1987 
CIBSE. Guide B, Heating, ventilating, air conditioning and refrigeration London, UK 2005

CIBSE. Guide A, Environmental design London UK 2006

Cook M, Yang T, Cropper P. "Thermal comfort in naturally ventilated classrooms: Application of coupled simulation models", In: Building Simulation 2011, 12th Conference of International Building Performance Simulation Association, Sydney, 14-16 November, 2011 pp2257-2262

Drakou A, Tsangrassoulis A, Roetzel A. "Occupant interaction with the interior environment in Greek dwellings during summer", In: Bodart M and Evrard A (Eds), In: Plea 2011-27th Conference on Passive and Low Energy Architecture Presses universitaires de Louvain Louvain-la-Neuve Belgium 2011 Vol. 1 pp475-480

EL.STAT. Statistical Database. In: Hell. Stat. Auth. www.statistics.gr 2014.

Ford B, Wilson R, Gillott M, Ibraheem O, Salmeron J, Sanchez FJ. "Passive downdraught evaporative cooling: performance in a prototype house", Build Res Inf 2012 40(3) pp290-304 doi: 10.1080/09613218.2012.669908

Georgakis C, Santamouris M. Experimental investigation of air flow and temperature distribution in deep urban canyons for natural ventilation purposes. Energy Build 2006 38(4) pp367-376 doi: 10.1016/j.enbuild.2005.07.009

Geros V, Santamouris M, Karatasou S, Tsangrassoulis A, Papanikolaou N. “On the cooling potential of night ventilation techniques in the urban environment”. Energy Build 2005 37(3) pp243-257 doi: 10.1016/j.enbuild.2004.06.024

Geros V, Santamouris M, Tsangrasoulis A, Guarracino G. "Experimental evaluation of night ventilation phenomena”, Energy Build 1999 29(2) pp141-154 doi: 10.1016/S03787788(98)00056-5

Givoni B. "Indoor temperature reduction by passive cooling systems", Sol Energy, Elsevier Ltd, 2011 85(8) pp1692-1726 doi: 10.1016/j.solener.2009.10.003

Givoni B. Passive and Low Energy Cooling of Buildings. Van Nostrand Reinhold, USA $1^{\text {st }}$ ed 1994 
Gong N, Tham KW, Melikov AK, Wyon DP, Sekhar SC, Cheong KW. "The Acceptable Air Velocity Range for Local Air Movement in the Tropics". HVAC\&R Res 2006 12(4) pp10651076. doi: 10.1080/10789669.2006.10391451

Graça GC da, Chen Q, Glicksman LR, Norford LK "Simulation of wind-driven ventilative cooling systems for an apartment building in Beijing and Shanghai", Energy and Build 2002 34(1) pp1-11 doi: 10.1016/S0378-7788(01)00083-4

Hammad F, Abu-Hijleh B. "The energy savings potential of using dynamic external louvers in an office building”, Energy Build 2010 42(10) pp1888-1895 doi:

10.1016/j.enbuild.2010.05.024

Hassid S, Santamouris M, Papanikolaou N, Linardi A, Georgakis C, Assimakopoulos DN. "The effect of the Athens heat island on air conditioning load", Energy Build 2000 32(2) pp131-141 doi: 10.1016/S0378-7788(99)00045-6

Hughes BR, Cheuk-Ming M. “A study of wind and buoyancy driven flows through commercial wind towers”. Energy Build 2011 43(7) pp1784-1791 doi: S0378778811001009

Jiru TE, Bitsuamlak GT. "Application of CFD in modelling wind-induced natural ventilation of buildings - A review”, Int J Vent 2010 9(2) pp131-147 doi: 10.5555/ijov.2010.9.2.131

Kolokotroni M, Zhang Y, Watkins R. "The London Heat Island and building cooling design", Sol Energy 2007 81(1) pp102-110 doi: 10.1016/j.solener.2006.06.005

Launder BE, Spalding DB. "The numerical computation of turbulent flows", Comput Methods Appl Mech Eng 1974 3(2) pp269-289 doi: 10.1016/0045-7825(74)90029-2

Ludwig JC, Mortimore S. PHOENICS-VR Reference Guide TR 326, (J C Ludwig,Ed.) Wimbledon Village London: CHAM. 2011

Martins NR, Carrilho da Graça G. "Validation of numerical simulation tools for wind-driven natural ventilation design”, Build Simul 2016 9(1) pp75-87 doi: 10.1007/s12273-015-0251-6

Montazeri H, Montazeri F, Azizian R, Mostafavi S. "Two-sided wind catcher performance evaluation using experimental, numerical and analytical modeling", Renew Energy 2010 35(7) pp1424-1435 doi: 10.1016/j.renene.2009.12.003 
Niachou K, Hassid S, Santamouris M, Livada I. "Comparative monitoring of natural, hybrid and mechanical ventilation systems in urban canyons”, Energy Build 200537 pp503-513 doi: 10.1016/j.enbuild.2004.09.016

Norton T, Sun DW, Grant J, Fallon R, Dodd V “Applications of computational fluid dynamics (CFD) in the modelling and design of ventilation systems in the agricultural industry: a review”, Bioresour Technol 200798 pp2386-2414 doi: 10.1016/j.biortech.2006.11.025

Papadopoulos AM, Oxizidis S, Papathanasiou L. "Developing a new library of materials and structural elements for the simulative evaluation of buildings' energy performance", Build Environ 2008 43(5) pp710-719 doi: 10.1016/j.buildenv.2007.01.049

Papakonstantinou K, Kiranoudis C, Markatos N. "Numerical simulation of air flow field in single-sided ventilated buildings”, Energy Build 2000 33(1) pp41-48 doi: 10.1016/S03787788(00)00063-3

Pavlou K, Vasilakopoulou K, Santamouris M. “The impact of several construction elements on the thermal performance of solar chimneys", Int J Vent 2007 8(3) pp277-285 doi:

10.5555/ijov.2009.8.3.277

Psomas T, Holzer P, Santamouris M. "A naturally ventilated efficient residential building under the impact of climate change", Int J Vent, 2014 13(2) pp169-178 doi: 10.5555/20444044-13.2.169

Salmeron JM, Sánchez FJ, Sánchez J, Álvarez S, Molina JL, Salmeron R. “Climatic applicability of downdraught cooling in Europe”. Archit Sci Rev, 2012 55(4) pp259-272 doi: $10.1080 / 00038628.2012 .723393$

Santamouris M. Advances in passive cooling. M. Santamouris ed. London UK, 1 st edn Earthscan 2007.

Santamouris M, Argiroudis K, Georgiou M, Livada I, Doukas P, Assimakopoulos M, Sfakianaki, A, Pavlou K, Geros V, Papaglastra M. "Indoor air quality in fifty residences in Athens", Int J Vent 2007a 5(4) pp367-80 doi: 10.5555/ijov.2007.5.4.367

Santamouris M, Kapsis K, Korres D, Livada I, Pavlou C, Assimakopoulos M. “On the relation between the energy and social characteristics of the residential sector", Energy Build 2007b 39(8) pp893-905 doi: 10.1016/j.enbuild.2006.11.001 
Santamouris M, Sfakianaki A, Pavlou K. "On the efficiency of night ventilation techniques applied to residential buildings", Energy Build 2010 42(8) pp1309-1313 doi:

10.1016/j.enbuild.2010.02.024

Spentzou E, Iddon CR, Grove M, Cook MJ. (2016) "Priority School Building Programme : An investigation into predicted occupant comfort during the heating season in naturally ventilated classrooms". In: Heiselberg PK (Ed) 12th REHVA World Congress: volume 5. Aalborg University, Department of Civil Engineering, Aalborg Denmark p349

Spentzou E. "Refurbishment of apartment buildings in the Mediterranean Region for natural ventilation: implications for building design”, Loughborough University PhD Thesis. 2015 pp1-369

Spentzou E, Cook M, Emmitt S. "Enhancing indoor comfort in existing apartment buildings in Athens using natural ventilation", In: BS2013, 13th Conf of International Building Performance Simulation Association, Chambéry France, 25-28 August 2013 pp1168-1175

Spentzou E, Cook M, Emmitt S. “Assessing natural cooling strategies in apartment buildings using de-coupled internal-external airflow simulations”, In: Malki-Epsthein L et al (Eds) 2014 Building Performance Simulation and Optimazation Conf, BSO14, IBPSA-England, UCL London, 23-24 June 2014 p85

Spentzou E, Cook MJ, Lin CL. "Natural ventilation assessment of an existing apartment building in the Mediterranean using time-dependent CFD”, In: Mathur J, Garg V. (Eds) 14th Conf of the International Building Performance Simulation Association, BS2015, IBPSA, Hyderabad India, 7-9 December 2015 pp672-679

Yun GY, Steemers K. "Behavioural, physical and socio-economic factors in household cooling energy consumption", Appl Energy 2011 88(6) pp2191-2200 doi:

10.1016/j.apenergy.2011.01.010 


\section{List of Tables}

Table 1 Computational mesh investigation of the external flow field. Total number of cells and cells in the windcatcher zone

\begin{tabular}{|l|c|c|c|c|}
\hline Type & Wind-catcher $(\mathrm{x}, \mathrm{y})$ & $\begin{array}{c}\text { Domain } \\
(\mathrm{x}, \mathrm{y}, \mathrm{z})\end{array}$ & $\begin{array}{c}\text { Total Number } \\
\text { of cells }\end{array}$ & $\begin{array}{c}\text { Driving Pressure } \\
\mathbf{( P a )}\end{array}$ \\
\hline Mesh 1 & $5 \times 10$ & $186 \times 161 \times 76$ & $2,275,896$ & $\mathbf{6 . 1 8}$ \\
Mesh 2 & $4 \times 7$ & $194 \times 170 \times 80$ & $2,638,400$ & $\mathbf{5 . 6 9 3}$ \\
Mesh 3 & $5 \times 9$ & $205 \times 182 \times 79$ & $2,947,490$ & $\mathbf{5 . 7 9}$ \\
Mesh 4 & $6 \times 11$ & $215 \times 189 \times 86$ & $3,494,610$ & $\mathbf{5 . 5 0 3}$ \\
Mesh 5 & $7 \times 12$ & $221 \times 198 \times 94$ & $4,113,252$ & $\mathbf{5 . 4 7}$ \\
Mesh 6 & $8 \times 13$ & $227 \times 199 \times 98$ & $4,426,954$ & -- \\
\hline
\end{tabular}

Table 2 Internal heat gains of each of the four occupied building spaces.

\begin{tabular}{|c|c|c|c|}
\hline Space & $\operatorname{Area}\left(\mathrm{m}^{2}\right)$ & Heat sources (Convective) & $\begin{array}{c}\text { Convective Heat } \\
\text { Total }\end{array}$ \\
\hline \multirow{3}{*}{ Bedroom 1} & \multirow{3}{*}{13.70} & 1 occupant seated $(51.1 \mathrm{~W})$ & \multirow{3}{*}{164 Watts } \\
\hline & & 1 computer $(53 \mathrm{~W})$ & \\
\hline & & Lighting $\left(4.32 \mathrm{~W}\right.$ per $\left.\mathrm{m}^{2}\right)$ & \\
\hline \multirow{3}{*}{ Bedroom 2} & \multirow{3}{*}{12.13} & 1 occupant seated $(51.1 \mathrm{~W})$ & \multirow{3}{*}{157 Watts } \\
\hline & & 1 computer $(53 \mathrm{~W})$ & \\
\hline & & Lighting $\left(4.32 \mathrm{~W}\right.$ per $\left.\mathrm{m}^{2}\right)$ & \\
\hline \multirow{2}{*}{ Kitchen } & \multirow{2}{*}{7.40} & 1 occupant seated $(51.1 \mathrm{~W})$ & \multirow{2}{*}{ 83.1 Watts } \\
\hline & & Lighting $\left(4.32 \mathrm{~W}\right.$ per $\left.\mathrm{m}^{2}\right)$ & \\
\hline \multirow{3}{*}{ Living Room } & \multirow{3}{*}{9.94} & 1 occupant light work (46.5W) & \multirow{3}{*}{ 120.6 Watts } \\
\hline & & Equipment $(31.2 \mathrm{~W})$ & \\
\hline & & Lighting (4.32W per $\left.\mathrm{m}^{2}\right)$ & \\
\hline
\end{tabular}




\section{List of Figures}

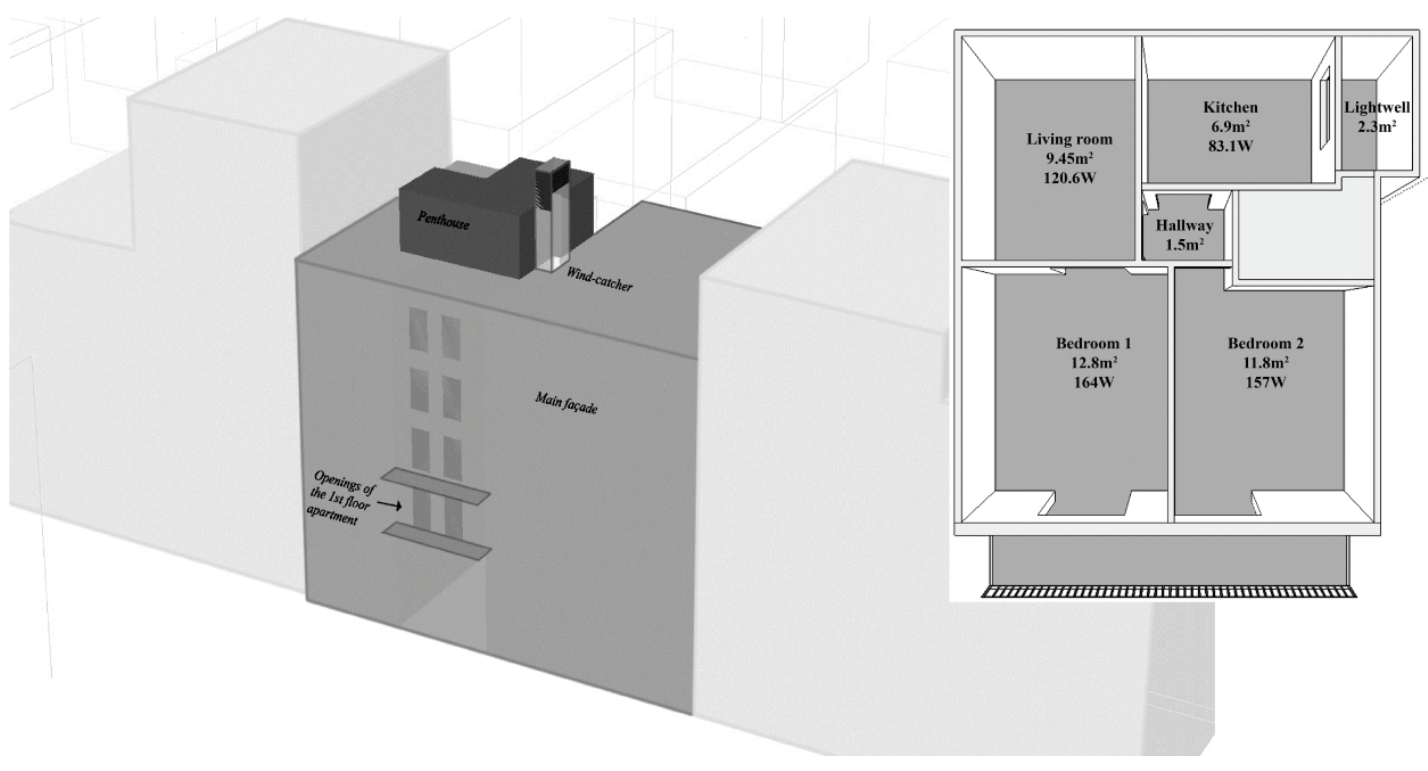

Figure 1 View of the three-dimensional model of the building in CFD (left) with the wind-catcher, and layout (right) of the apartment studied (nts) showing the internal heat gains

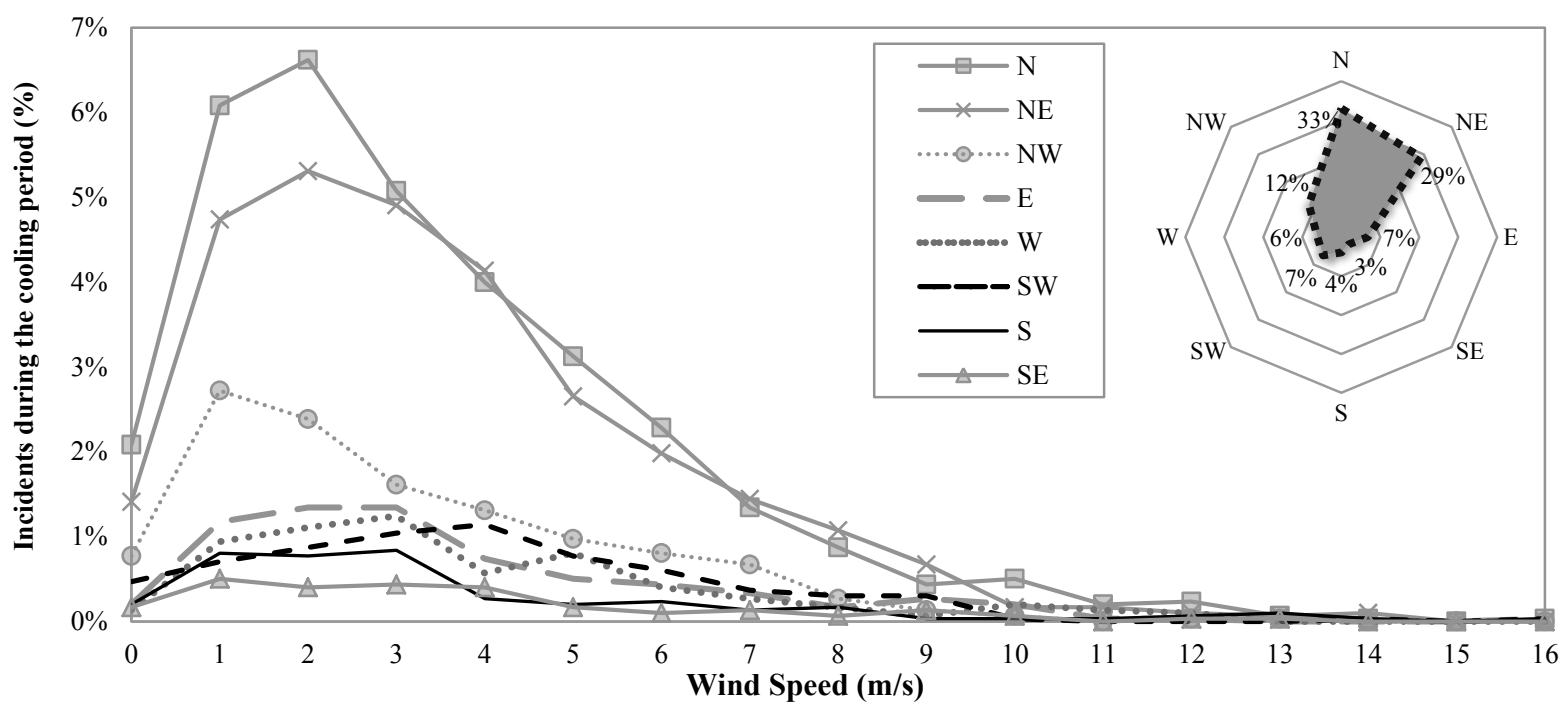

Figure 2 Incidents of wind speed and direction (\%) during the cooling period

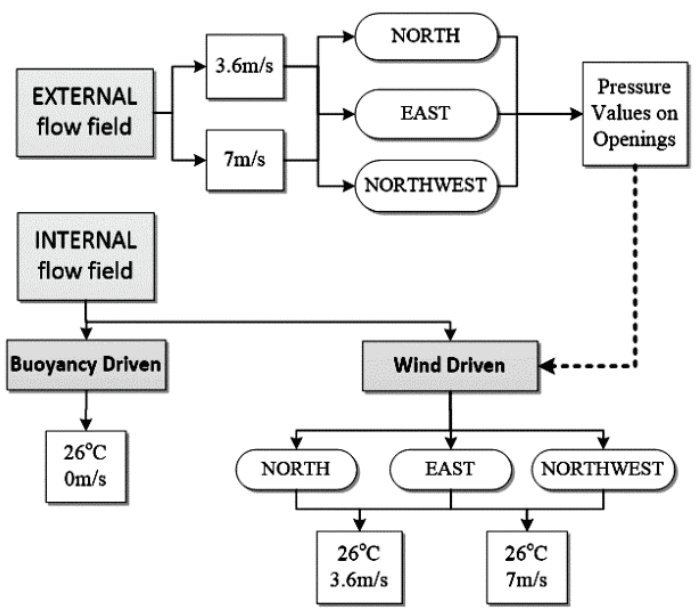

Figure 3 Flow diagram of the de-coupled internal-external CFD simulations performed, showing inputs and outputs, repeated for each natural ventilation strategy investigated 


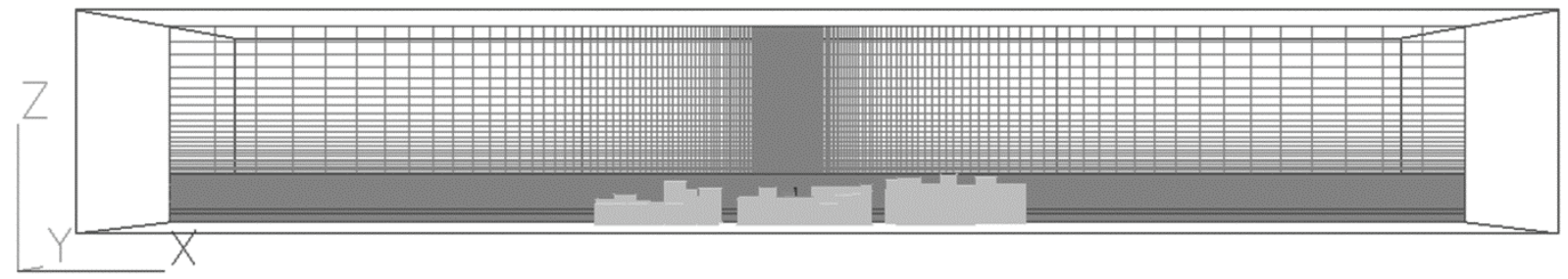

Figure 4 Representation of the surrounding buildings and computational mesh for the study of the external flow

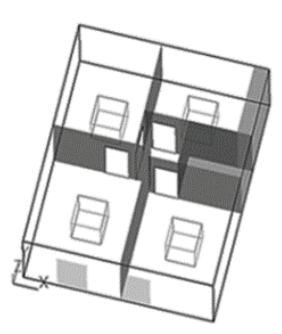

Single-sided ventilation [SS] $6.45 \times 7.7 \times 3 m$ $61,69,20$ cells

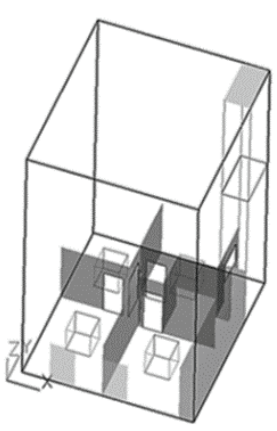

Cross ventilation $[\mathrm{CV}]$ $7.05 \times 7.7 \times 12.8 \mathrm{~m}$ $61,69,38$ cells

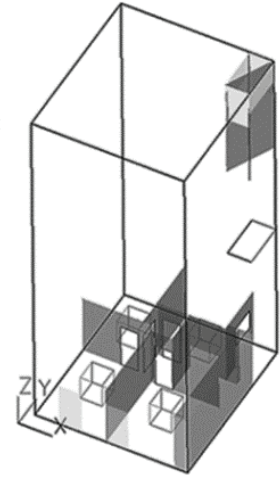

Wind-catcher [WC] $7.05 \times 7.7 \times 17 \mathrm{~m}$ $61,69,51$ cells

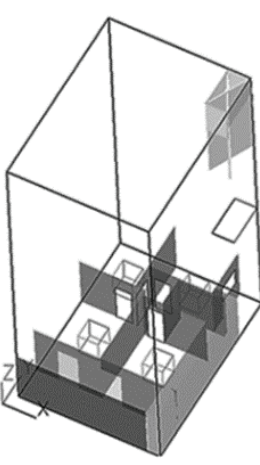

Dynamic façade [DF \& WC] $7.05 \times 9.3 \times 17 \mathrm{~m}$ $61,83,51$ cells

Figure 5 Three-dimensional models of the apartment in CFD showing computational domain dimensions and mesh size $(x, y, z)$

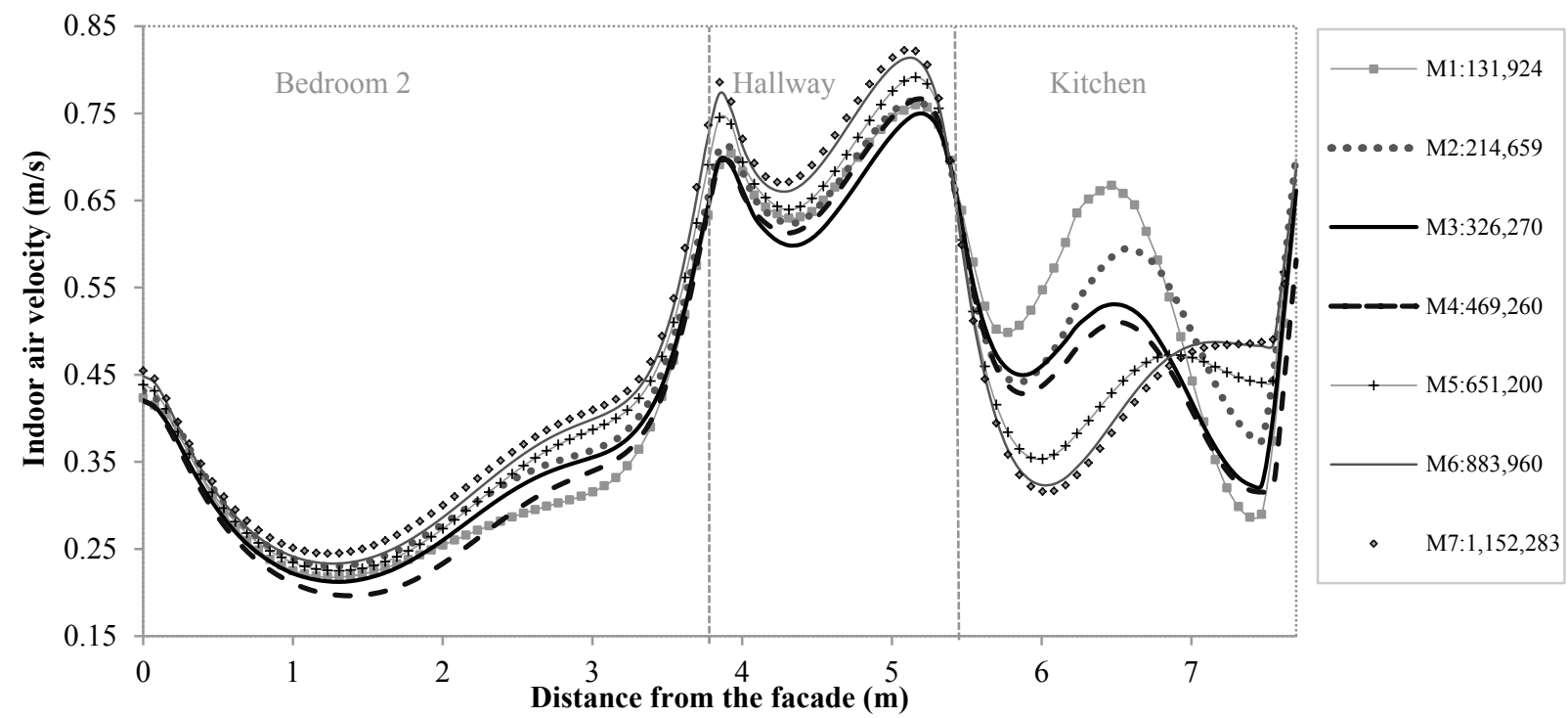

Figure 6 Indoor air velocities $(\mathrm{m} / \mathrm{s})$ at 100 points along a measuring line (from 3.65, 0, 1.5 to 3.65, 9.3, 1.5) for 7 different computational meshes
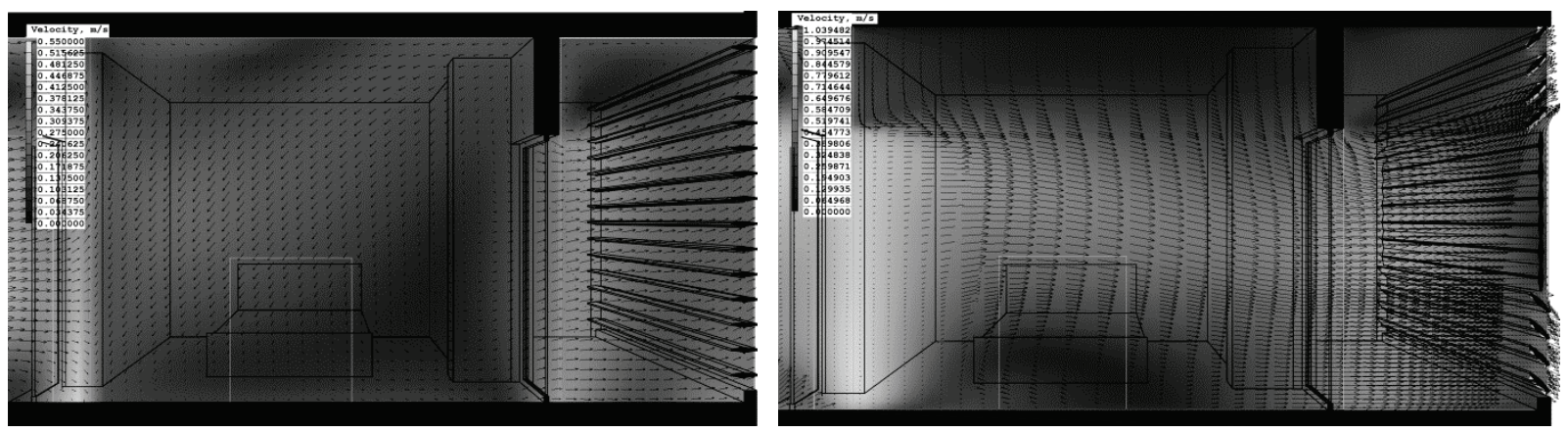

Figure 7 Velocity contours and vectors (y, z cross section) showing two louvre configurations the balcony and the second bedroom $\left(3.6 \mathrm{~m} / \mathrm{s}\right.$ east wind at $\left.26^{\circ} \mathrm{C}\right)$

Page $\mathbf{2 9}$ of $\mathbf{3 2}$ 


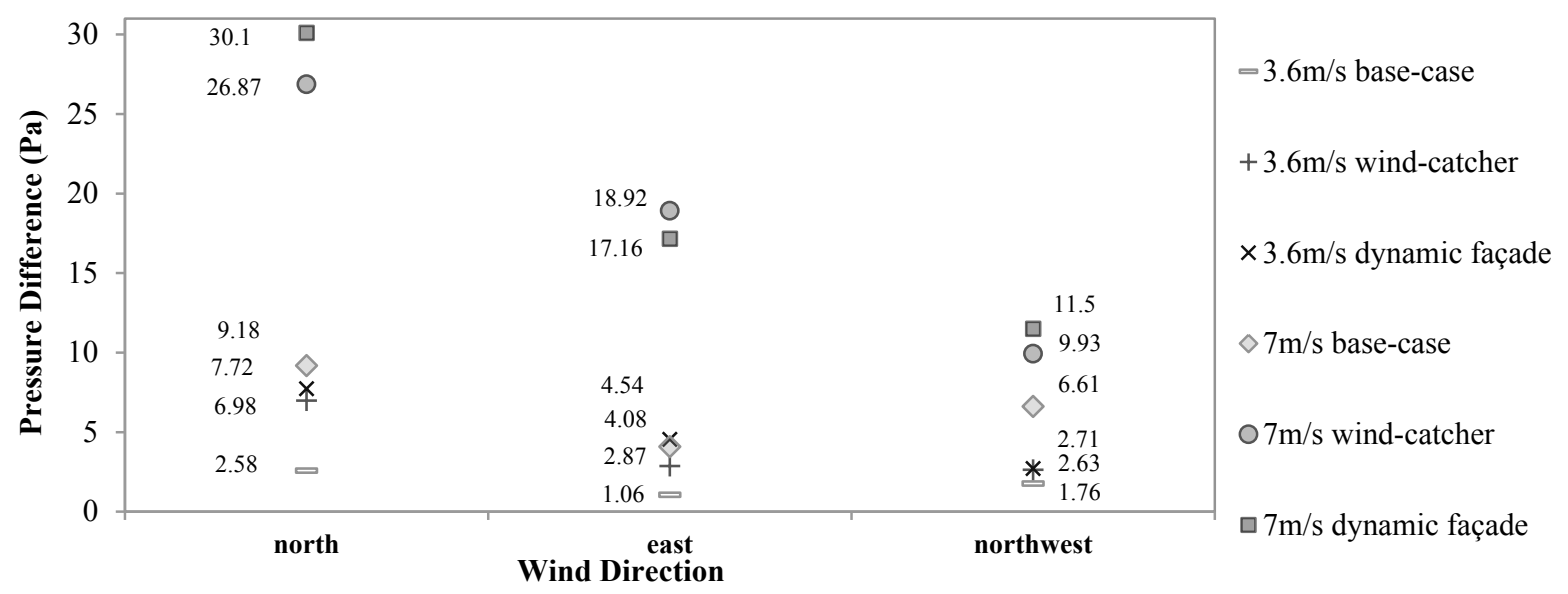

Figure 8 Predicted driving pressures for $3.6 \mathrm{~m} / \mathrm{s}$ and $7 \mathrm{~m} / \mathrm{s}$ wind speed, 3 wind directions and 3 ventilation strategies

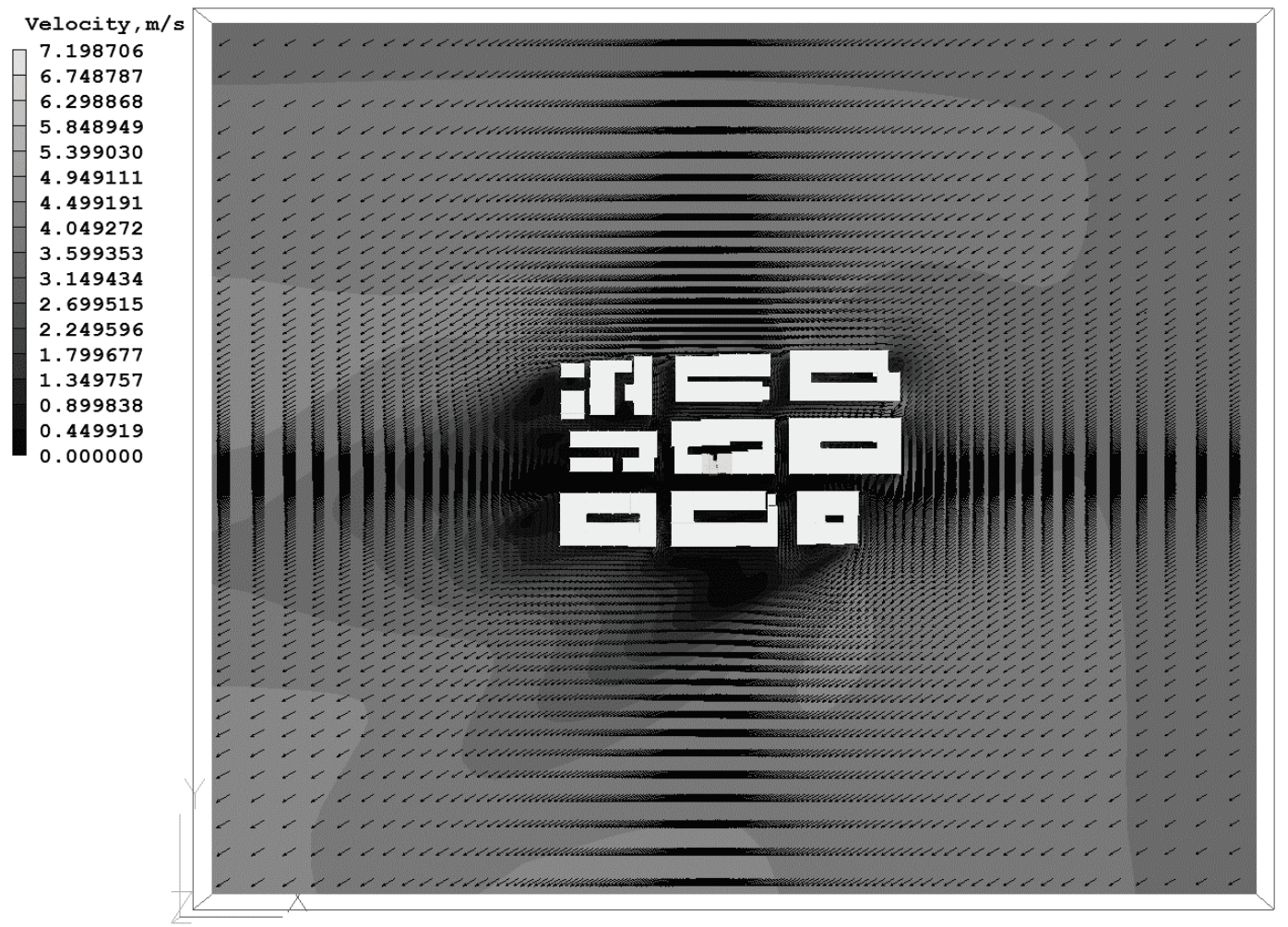

Figure 9 Velocity vectors (x,y plane) for north wind direction of $7 \mathrm{~m} / \mathrm{s}$.
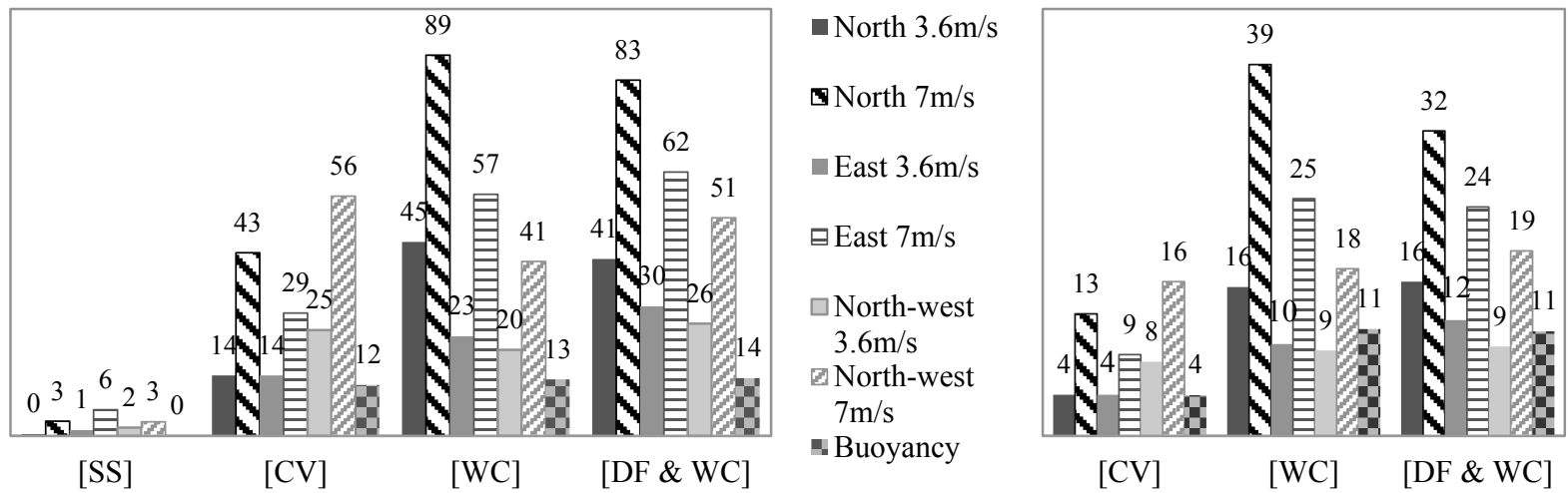

Figure 10 Predicted air change rates (ach ${ }^{-1}$ ) of the case study apartment for all natural ventilation strategies (left) and during the part operation of the airshaft (right) 


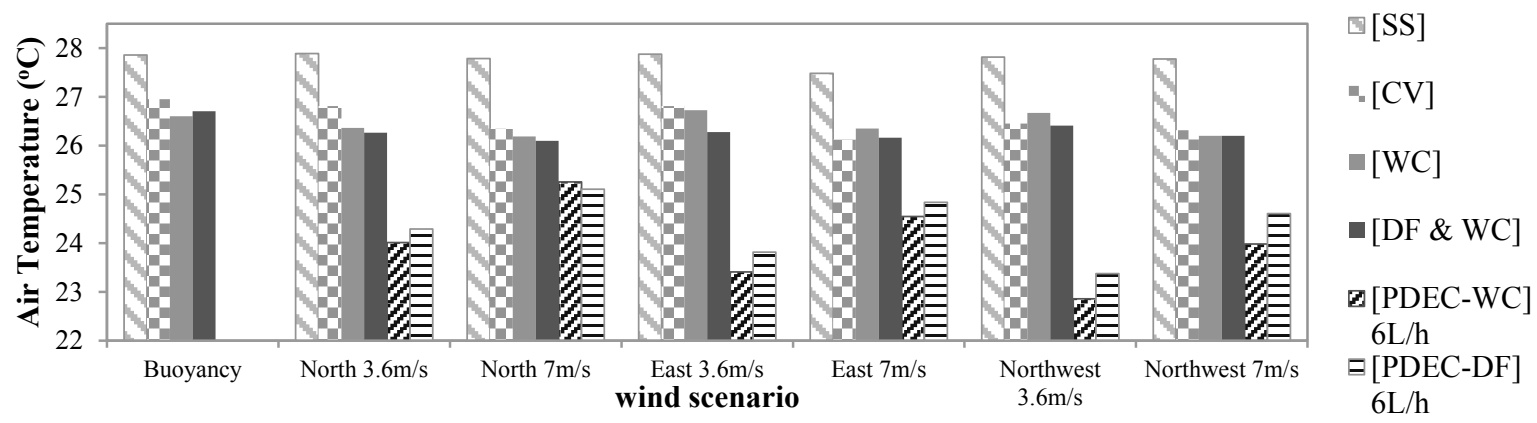

Figure 11 Average values of indoor air temperature $\left({ }^{\circ} \mathrm{C}\right)$ predicted at a horizontal plane (at $1.50 \mathrm{~m}$ height above the apartment floor level) for $3.6 \mathrm{~m} / \mathrm{s}$ and $7 \mathrm{~m} / \mathrm{s}$ wind incidents (ambient temperature $=26^{\circ} \mathrm{C}$ )
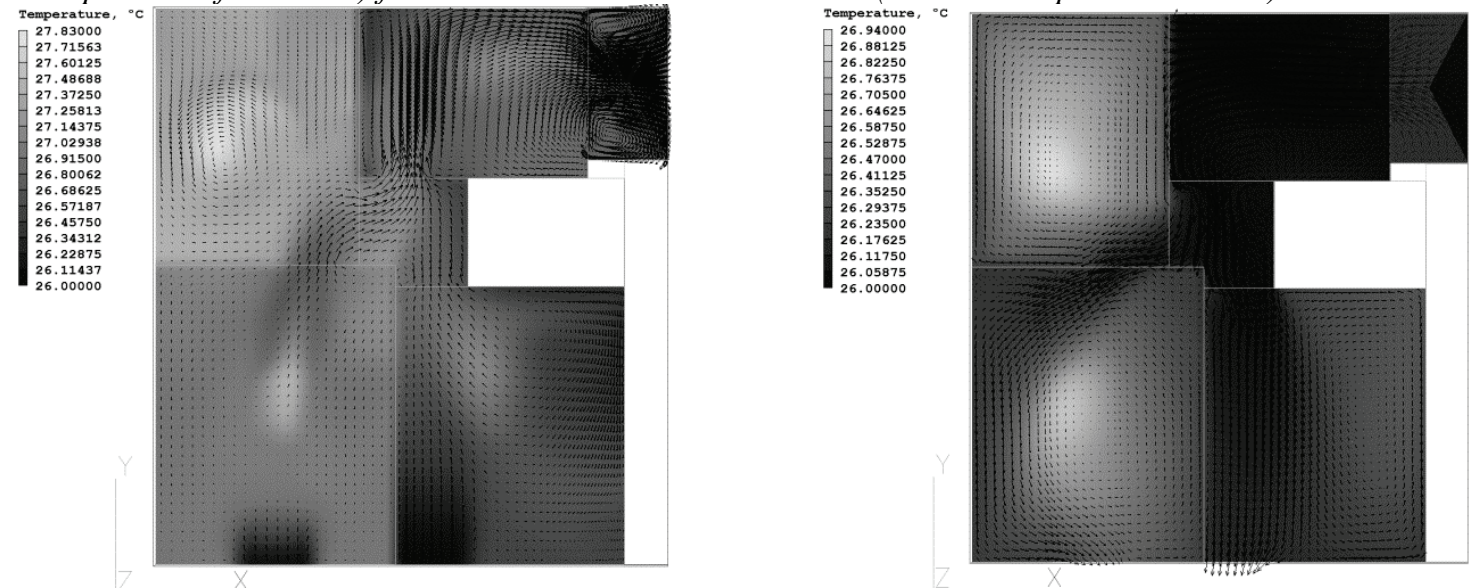

Figure 12 Temperature contours and vectors on plan view (at 1.50m height above the apartment floor level), for buoyancy-driven (left) and for wind-driven (north, $7 \mathrm{~m} / \mathrm{s}$ ) (right) ventilation of the [WC] ventilation strategy (ambient temperature $=26^{\circ} \mathrm{C}$ )

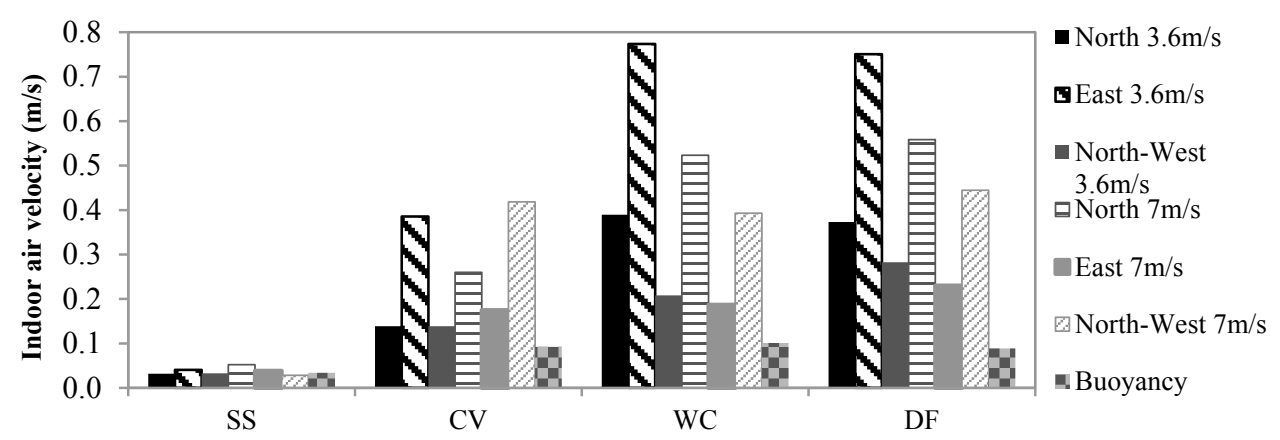

Figure 13 Average indoor air speeds $(\mathrm{m} / \mathrm{s})$ across all spaces calculated at a horizontal plane at $1.5 \mathrm{~m}$ height above the apartment floor

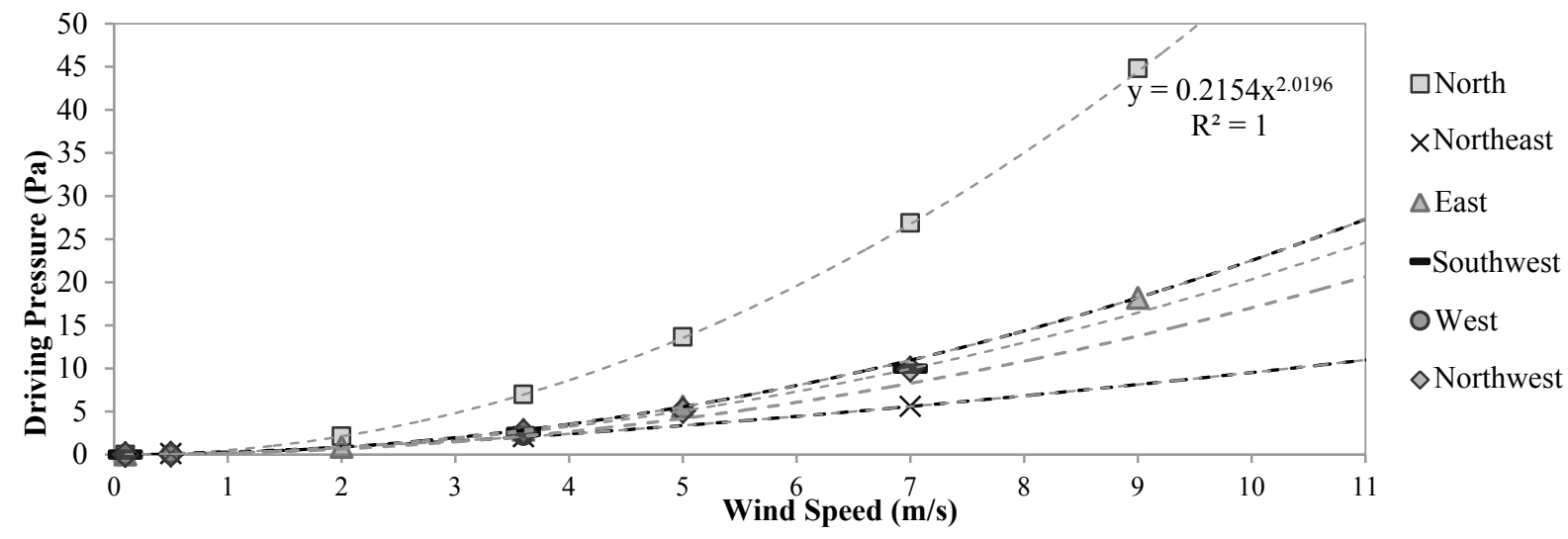

Figure 14 Relation of wind speed and pressure difference across the openings for the [WC] strategy

Page 31 of 32 